\title{
Two New Sesquiterpenoids and Two New Prenylated Phenylpropanoids from Illicium fargesii, and Neuroprotective Activity of Macranthol
}

\author{
Miyako Moriyama, ${ }^{a}$ Jian-Mei Huang,${ }^{b}$ Chun-Shu Yang, ${ }^{b}$ Miwa Kubo, ${ }^{a}$ Kenichi Harada, ${ }^{a}$ \\ Hideaki HiokI, ${ }^{a}$ and Yoshiyasu FUKUYAMA*, \\ ${ }^{a}$ Faculty of Pharmaceutical Sciences, Tokushima Bunri University; 180 Yamashiro-cho, Tokushima 770-8514, Japan: and \\ ${ }^{b}$ Faculty of Pharmaceutical Sciences, Beijing University of Chinese Medicine; Beijing 100029, P. R. China. \\ Received April 11, 2008; accepted May 9, 2008; published online May 16, 2008
}

Two new seco-prezizaane-type sesquiterpenoids 1,2 and two new prenylated phenylpropanoids 4, 5 were isolated along with 15 known compounds from Illicium fargesii. The structures of 1,2 were elucidated as $10-O-(E)-$ and 10-O-(Z)-cinnamoyl-2-oxo-6-deoxyneoanisatin by analysis of spectroscopic data and by comparison of their NMR data with those of previously reported 2-oxo-6-deoxyneoanisatin (3), respectively, whereas the structures of 4, 5 were identified as 4-allyl-2-(3-methylbut-2-en-1-yl)phenol and 4-allyl-2-(2-methylbut-3-en-2-yl)phenol, respectively, on the basis of spectroscopic data. Among the isolated compounds, macranthol (7) was found to have neuroprotective activity at 5-10 $\mu \mathrm{M}$ in rat cortical neurons cultured in DMEM/ $\mathrm{N}_{2}$ medium.

Key words Illicium fargesii; seco-prezizaane-type sesquiterpenoid; prenylated phenylpropanoid; neuroprotective activity

Over $70 \%$ of the species present in Illiciaceae are distributed in China, mostly indigenous to Southwestern and Eastern China. Chinese star anise, Illicium verum Ноок. f., and I. jiadifengpi are included in the Pharmacopoeia of the People's Republic of China (Edition 1995). ${ }^{1)}$ Illicium fargesii (Illiciaceae), a medium-sized flowering tree, is indigenous to southwestern China and its fruit is used locally as a folk medicine for the treatment of rheumatism. As part of our continuing studies on neurotrophic-like active compounds in Illicium species, ${ }^{2)}$ we investigated the chemical constituents of the pericarps of I. fargesii, collected in Sichuan, China, resulting in the isolation of two new seco-prezizaane-type sesquiterpenoids 1, 2 and two new prenylated phenylpropanoids $4, \mathbf{5}$. In this paper, we report the structure elucidation of new compounds and the neurotrophic activity of isolated compounds in the primary cultured rat cortical neurons.

The $\mathrm{MeOH}$ extract of dried pericarps of I. fargesii was subjected to repeating column chromatography over silica gel and Sephadex LH-20, and finally purified by reversed-phase HPLC, resulting in the isolation of new compounds $\mathbf{1}, \mathbf{2}$, 4, and 5, together with 15 known compounds, anisatin, ${ }^{3)} 2$ oxo-6-deoxyneoanisatin (3), ${ }^{4}$ 3,4-dehydro-2-oxo-anisatin, ${ }^{4}$ dictagymnin, ${ }^{5)} 3$-methyl-2-buten-1-yl-cinnamate, ${ }^{6}$ pyrocatechol, ${ }^{7)}$ geranylcinnamate, ${ }^{8}$ cinnamic acid, 2-methoxyphenol, honokiol, ${ }^{9)}$ magnolol, ${ }^{9)}$ isomagnolol, ${ }^{10)}$ isoduinnianol $(6),{ }^{11)}$ macranthol (7), ${ }^{12)}$ and integrifoliolin. ${ }^{13)}$

Compound 1 was isolated from a colorless, amorphous powder and has the molecular formula $\mathrm{C}_{24} \mathrm{H}_{24} \mathrm{O}_{8}$, deduced from high-resolution (HR) EI-MS at $m / z 440[\mathrm{M}]^{+}$. The IR spectrum of 1 showed the presence of hydroxy $\left(3854 \mathrm{~cm}^{-1}\right)$, $\beta$-lactone $\left(1823 \mathrm{~cm}^{-1}\right)$, ester $\left(1735 \mathrm{~cm}^{-1}\right)$ and aromatic $\left(1633 \mathrm{~cm}^{-1}\right)$ groups. The presence of an $(E)$-cinnamoyl group was supported not only by UV absorption at $284 \mathrm{~nm}$ and ${ }^{1} \mathrm{H}-\mathrm{NMR}$ signals at $\delta_{\mathrm{H}} 6.95(1 \mathrm{H}, \mathrm{d}, J=16.1 \mathrm{~Hz}), 7.25$ $(2 \mathrm{H}, \mathrm{dd}, J=7.4,7.1 \mathrm{~Hz}), 7.31$ (1H, ddd, $J=7.4,7.1,1.5 \mathrm{~Hz})$, $7.47(2 \mathrm{H}, \mathrm{dd}, J=7.1,1.5 \mathrm{~Hz}), 7.98(1 \mathrm{H}, \mathrm{d}, J=16.1 \mathrm{~Hz})$, but also by the base peak observed at $\mathrm{m} / z 131[\mathrm{PhCH}=\mathrm{CHCO}]^{+}$ on EI-MS. NMR spectroscopic data (Table 1) of $\mathbf{1}$ were similar to those of 2-oxo-6-deoxyneoanisatin (3), previously re- ported by Kouno, ${ }^{4)}$ except for the presence of the cinnamoyl group. The $\mathrm{H}-10$ and $\mathrm{C}-11$ resonances in $\mathbf{1}$ were significantly shifted downfield to $\delta_{\mathrm{H}} 6.20$ and upfield to $\delta_{\mathrm{C}} 168.7$, respectively, in comparison to NMR data $\left(\delta_{\mathrm{H}} 4.53\right.$ for H-10; $\delta_{\mathrm{C}}$ 174.6 for $\mathrm{C}-11$ ) of 3 . This implied that the cinnamonyl group was attached to oxygen at the $\mathrm{C}-10$ position. The structure was further confirmed by analysis of 2D NMR data $(\mathrm{H} / \mathrm{H}$ COSY, HMQC, HMBC, and NOESY). As summarized in Fig. 1, the HMBC correlations indicated the plain structure of $\mathbf{1}$ corresponding to that of $\mathbf{3}$, in particular, the HMBC correlation between $\mathrm{H}-10$ at $\delta_{\mathrm{H}} 6.20(\mathrm{~s})$ and the cinnamoyl carbonyl carbon at $\delta_{\mathrm{C}} 165.2$ provided evidence for the C-10 position of the cinnamoyl moiety. In addition, the NOE data, as shown in Fig. 1, proved the relative stereochemistry of $\mathbf{1}$ to be the same as that of $\mathbf{3}$. Thus, based on the aforementioned spectroscopic data, compound $\mathbf{1}$ was elucidated as $10-O-(E)$ -

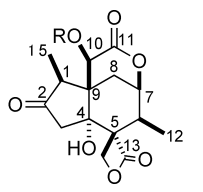

$$
1 \mathrm{R}=\mathrm{COCH} \stackrel{E}{=} \mathrm{CHC}_{6} \mathrm{H}_{5}
$$

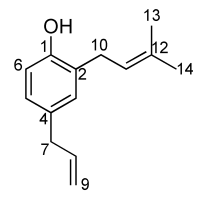
$\begin{aligned} 2 \mathrm{R} & =\mathrm{COCH}=\mathrm{CHC}_{6} \mathrm{H}_{5} \\ 3 \mathrm{R} & =\mathrm{H}\end{aligned}$
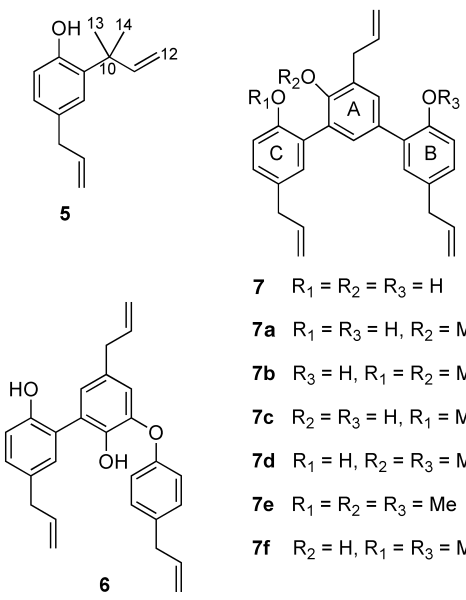

$7 \quad \mathrm{R}_{1}=\mathrm{R}_{2}=\mathrm{R}_{3}=\mathrm{H}$

7a $\quad R_{1}=R_{3}=H, R_{2}=M e$

7b $R_{3}=H, R_{1}=R_{2}=M e$

7c $R_{2}=R_{3}=H, R_{1}=M e$

7d $\quad R_{1}=H, R_{2}=R_{3}=M e$

$7 e \quad R_{1}=R_{2}=R_{3}=M e$

$7 f \quad R_{2}=H, R_{1}=R_{3}=M e$ 
Table 1. ${ }^{13} \mathrm{C}-(150 \mathrm{MHz})$ and ${ }^{1} \mathrm{H}-(600 \mathrm{MHz}) \mathrm{NMR}$ Data ${ }^{a)}$ of $\mathbf{1}$ and $\mathbf{2}$

\begin{tabular}{|c|c|c|c|c|}
\hline \multirow{2}{*}{ Position } & \multicolumn{2}{|r|}{1} & \multicolumn{2}{|r|}{2} \\
\hline & $\delta_{\mathrm{C}}$ & $\delta_{\mathrm{H}}$ & $\delta_{\mathrm{C}}$ & $\delta_{\mathrm{H}}$ \\
\hline 1 & 48.7 & $3.38(\mathrm{q}, 7.4)^{b)}$ & 48.8 & $3.36(\mathrm{q}, 7.1)$ \\
\hline 2 & 213.8 & & 213.8 & \\
\hline $3 \alpha$ & 45.7 & $3.66(\mathrm{~d}, 18.3)$ & 45.7 & $3.41(\mathrm{~d}, 18.2)$ \\
\hline $3 \beta$ & & $2.93(\mathrm{~d}, 18.3)$ & & $2.92(\mathrm{~d}, 18.2)$ \\
\hline 4 & 77.2 & & 77.3 & \\
\hline 5 & 66.3 & & 66.3 & \\
\hline 6 & 35.3 & $3.36(\mathrm{qd}, 7.4,1.9)$ & 35.4 & $3.35(\mathrm{qd}, 7.1,1.9)$ \\
\hline 7 & 79.6 & $4.68(\mathrm{ddd}, 3.8,1.9,1.9)$ & 79.7 & $4.64(\mathrm{ddd}, 3.8,1.9,1.9)$ \\
\hline $8 \alpha$ & 30.9 & $2.87(\mathrm{dd}, 14.0,1.9)$ & 31.0 & $2.82(\mathrm{dd}, 14.2,1.9)$ \\
\hline $8 \beta$ & & $2.45(\mathrm{dd}, 14.0,3.8)$ & & $2.39(\mathrm{dd}, 14.2,3.8)$ \\
\hline 9 & 50.7 & & 50.8 & \\
\hline 10 & 69.7 & $6.20(\mathrm{~s})$ & 69.6 & $6.05(\mathrm{~s})$ \\
\hline 11 & 168.7 & & 168.7 & \\
\hline 12 & 12.6 & $1.31(3 \mathrm{H}, \mathrm{d}, 7.4)$ & 12.8 & $1.29(3 \mathrm{H}, \mathrm{d}, 7.1)$ \\
\hline 13 & 171.0 & & 171.1 & \\
\hline \multirow[t]{2}{*}{14} & 64.1 & $4.62(\mathrm{~d}, 6.7)$ & 64.1 & $4.49(\mathrm{~d}, 6.7)$ \\
\hline & & $4.79(\mathrm{~d}, 6.7)$ & & $4.54(\mathrm{~d}, 6.7)$ \\
\hline 15 & 7.3 & $1.20(3 \mathrm{H}, \mathrm{d}, 7.4)$ & 7.4 & $1.14(3 \mathrm{H}, \mathrm{d}, 7.1)$ \\
\hline $1^{\prime}$ & 165.2 & & 164.1 & \\
\hline $2^{\prime}$ & 116.9 & $6.95(\mathrm{~d}, 16.1)$ & 118.0 & $6.15(\mathrm{~d}, 12.6)$ \\
\hline $3^{\prime}$ & 148.0 & $7.98(\mathrm{~d}, 16.1)$ & 147.0 & $7.10(\mathrm{~d}, 12.6)$ \\
\hline $4^{\prime}$ & 134.3 & & 135.0 & \\
\hline $5^{\prime}, 9^{\prime}$ & 129.0 & $7.47(2 \mathrm{H}, \mathrm{dd}, 7.1,1.5)$ & 128.8 & $7.83(2 \mathrm{H}, \mathrm{dd}, 7.2,1.9)$ \\
\hline $6^{\prime}, 8^{\prime}$ & 129.2 & $7.25(2 \mathrm{H}, \mathrm{dd}, 7.4,7.1)$ & 130.8 & $7.33(2 \mathrm{H}, \mathrm{t}, 7.2)$ \\
\hline $7^{\prime}$ & 131.2 & $7.31(\mathrm{tt}, 7.4,1.5)$ & 130.2 & $7.30(\mathrm{td}, 7.2,1.9)$ \\
\hline $4-\mathrm{OH}$ & & $8.20(\mathrm{~s})$ & & $8.34(\mathrm{~s})$ \\
\hline
\end{tabular}

a) Measured in $\mathrm{C}_{5} \mathrm{D}_{5} \mathrm{~N}$ and assignments based on HMQC and HMBC. b) $J$ in $\mathrm{Hz}$.

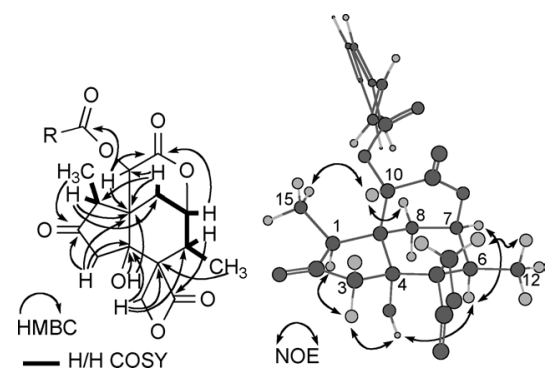

Fig. 1. Selected HMBC and NOESY Correlations of $\mathbf{1}$

cinnamoyl-2-oxo-6-deoxyneoanisatin.

Compound $\mathbf{2}$ had the same molecular formula as $\mathbf{1}$ and its NMR data (Table 1) were found to be similar to those of 1 except for a small coupling constant value $(12.6 \mathrm{~Hz})$ between $\mathrm{H}-2^{\prime}$ and $\mathrm{H}-3^{\prime}$ assignable to a cinnamoyl group. Both molecular and base ion peaks at $\mathrm{m} / \mathrm{z} 440$ and 131 were observed on the EI-MS. These spectral data disclosed that $\mathbf{2}$ is a $Z$ isomer of the cinnamoyl ester unit bonded to $\mathrm{C}-10$ of 1 . The $2 \mathrm{D}$ NMR data of 2, including HMBC and NOESY, were consistent with those of $\mathbf{1}$ except for a $Z$ stereochemistry of the cinnamoyl group; thus, the structure of $\mathbf{2}$ was represented as 10 $O$-(Z)-cinnamoyl-2-oxo-6-deoxyneoanisatin.

The molecular formula of compound $\mathbf{4}$ was determined as $\mathrm{C}_{14} \mathrm{H}_{18} \mathrm{O}$ by HR-EI-MS at $\mathrm{m} / z 202[\mathrm{M}]^{+}$, and its IR revealed the presence of a hydroxy group $\left(3385 \mathrm{~cm}^{-1}\right)$ and a benzene ring $\left(1639 \mathrm{~cm}^{-1}\right)$. The ${ }^{1} \mathrm{H}-\mathrm{NMR}$ of 4 contained signals due to an allyl group at $\delta_{\mathrm{H}} 3.20(2 \mathrm{H}, \mathrm{dd}, J=6.6,1.8 \mathrm{~Hz}), 4.99(1 \mathrm{H}$, $\mathrm{dt}, J=10.2,1.8 \mathrm{~Hz}), 5.02(1 \mathrm{H}, \mathrm{dt}, J=16.8,1.8 \mathrm{~Hz})$, and 5.91 $(1 \mathrm{H}, \mathrm{ddt}, J=16.8,10.2,6.6 \mathrm{~Hz})$, a prenyl group at $\delta_{\mathrm{H}} 1.56$ $(6 \mathrm{H}, \mathrm{brs}), 3.32(2 \mathrm{H}, \mathrm{d}, J=7.3 \mathrm{~Hz})$, and $5.34(1 \mathrm{H}, \mathrm{tq}, J=7.3$,

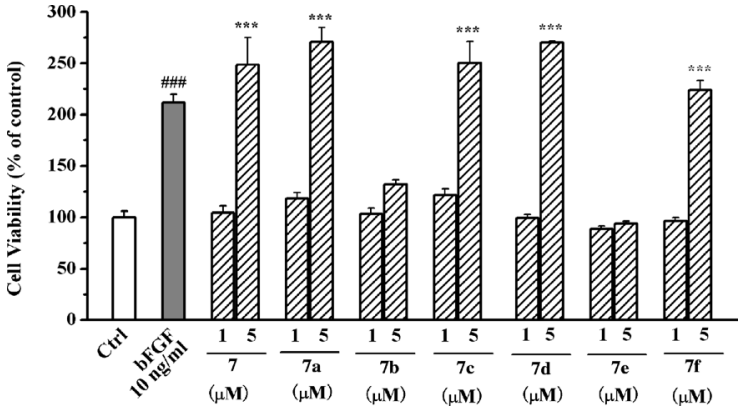

Fig. 2. Neuroprotective Activity of Macranthol (7) and Its $O$-Methyl Derivatives $7 \mathbf{a}-\mathbf{f}$

In each group, average viability was calculated from 6 wells of one plate and normalized as a percent of the control. Data were expressed as the mean \pm S.E. $(n=6)$. Differences between groups were tested with one-way ANOVA followed by Bonferroni post hoc means comparison or Student's $t$-test. \#\#,*** $p<0.001$ compared with control. Data were derived from one of three repeated experiments with similar results.

$1.5 \mathrm{~Hz}$ ), and a set of ABX-type aromatic protons at $\delta_{\mathrm{H}} 6.50$ $(1 \mathrm{H}, \mathrm{d}, J=8.1 \mathrm{~Hz}), 6.85(1 \mathrm{H}, \mathrm{dd}, J=8.1,2.2 \mathrm{~Hz})$, and 6.96 $(1 \mathrm{H}, \mathrm{d}, J=2.2 \mathrm{~Hz})$. These spectroscopic data implied that 4 was a prenylated allylphenol. The $\mathrm{C}-2$ position of the prenyl group was defined by HMBC correlations of $\mathrm{H}-10$ to $\mathrm{C}-1\left(\delta_{\mathrm{C}}\right.$ $153.1)$ and $\mathrm{C}-2\left(\delta_{\mathrm{C}} 127.4\right)$ signals. In addition, the methylene $\mathrm{H}_{2}-7$ of the allyl group showed the HMBC correlation to C-4 $\left(\delta_{\mathrm{C}} 132.1\right), \mathrm{C}-3\left(\delta_{\mathrm{C}} 130.5\right)$ and C-5 $\left(\delta_{\mathrm{C}} 127.6\right)$ resonances, indicating that the allyl group was substituted at the $\mathrm{C}-4$ position; thus, the structure of $\mathbf{4}$ was determined to be 4-allyl-2(3-methylbut-2-en-1-yl)phenol.

Compound $\mathbf{5}$ was found to have the same molecular formula as $\mathbf{4}$ from the HR-EI-MS. Spectroscopic data, including ${ }^{1} \mathrm{H}$ - and ${ }^{13} \mathrm{C}-\mathrm{NMR}$ data, indicated that 5 was also a $1,2,4-$ trisubstituted phenol having an allyl group and a $\mathrm{C} 5$ unit. This C5 unit turned out to be a 1,1-dimethylallyl group based on the NMR data at $\delta_{\mathrm{H}} 1.40(6 \mathrm{H}, \mathrm{s}), 5.32(1 \mathrm{H}, \mathrm{dd}, J=17.6$, $0.7 \mathrm{~Hz}), 5.32(1 \mathrm{H}, \mathrm{dd}, J=10.6,0.7 \mathrm{~Hz})$, and $6.19(1 \mathrm{H}, \mathrm{dd}$, $J=17.6,10.6 \mathrm{~Hz}$ ), including their HMBC correlations with the quaternary carbon resonated at $\delta_{\mathrm{C}} 40.3$. In the HMBC experiment, methylene $\mathrm{H}_{2}-7$ of the allyl group correlated to $\mathrm{C}-4$ $\left(\delta_{\mathrm{C}} 132.0\right), \mathrm{C}-3\left(\delta_{\mathrm{C}} 126.4\right)$ and $\mathrm{C}-5\left(\delta_{\mathrm{C}} 128.1\right)$ resonances and, furthermore, the methyl protons of the 1,1-dimethylallyl unit correlated to $\mathrm{C}-10\left(\delta_{\mathrm{C}} 40.3\right), \mathrm{C}-2\left(\delta_{\mathrm{C}} 131.9\right)$ and $\mathrm{C}-11$ $\left(\delta_{\mathrm{C}} 147.9\right)$ carbons. On the basis of the aforementioned spectroscopic data, the structure of $\mathbf{5}$ was assigned as 4-allyl-2(2-methylbut-3-en-2-yl)phenol.

We previously reported that honokiol and magnolol have promising neurotrophic properties, ${ }^{14)}$ and also isodunnianol (6) exhibited neurite-outgrowth promoting activity. ${ }^{15}$ ) The compounds isolated in the present study, however, had no effect on the morphology of rat cortical neurons cultured in Neurobasal medium supplemented with B-2 $7^{14,16)}$ at $10 \mu \mathrm{M}$, except for honokiol, magnolol and isodunnianol, whereas macranthol (7) was found to exhibit neuroprotective activity in rat cortical neurons cultured in DMEM/ $\mathrm{N}_{2}$ medium ${ }^{14,16)}$ at 5-10 $\mu \mathrm{M}$ (Fig. 2). To understand which hydroxy groups in 7 are responsible for neuroprotective activity, six $O$-methylated derivatives $7 \mathbf{a}-\mathbf{f}^{17)}$ were prepared by treatment of 7 with trimethylsilyldiazomethane $\left(\mathrm{TMSCHN}_{2}\right)$. The assay results shown in Fig. 2 suggested that one of two hydroxy groups on the $\mathrm{A}$ and $\mathrm{C}$ rings is essential for neuroprotective activity, but the hydroxy group on the B ring is not necessary. Taking 
a detailed look at the structure of 7, two biaryl units are present in the molecule, corresponding to magnolol (A-C ring) and honokiol (A-B ring) parts. From the present structure-activity relationships of methylated analogues, the magnolol part was proved to play a more important role in neuroprotective activity than the honokiol part. This conclusion is consistent with the fact that magnolol showed more potent neuroprotective activity than honokiol. ${ }^{14)}$ The present studies encourage us to develop potent neuroprotective agents from magnolol, a readily available natural product in a large amount, by modification of the biaryl structure with appropriate substituents. Further study is now underway along this line.

\section{Experimental}

General Optical rotations were measured on a JASCO P-1030 digital polarimeter. IR and UV spectra were recorded on a JASCO FT/IR-410 infrared and a Shimadzu UV-1650PC spectrophotometer, respectively. ${ }^{1} \mathrm{H}-$ NMR $(600 \mathrm{MHz})$ and ${ }^{13} \mathrm{C}-\mathrm{NMR}(150 \mathrm{MHz})$ spectra were measured on a Varian Unity 600 instrument. NMR assignments were made using DEPT, H-H COSY, HMQC, and HMBC experiments. Chemical shifts are expressed as $\delta$ (ppm) with trimethylsilane (TMS) as the internal standard. MS spectra were recorded on a JEOL JMS-AX 500 instrument. Silica gel column chromatography was performed on Wako-gel C-300 and Silica gel 60N (Kanto Chemical Co., Ltd.). HPLC was performed on a JASCO PU-1580 HPLC system equipped with a JASCO UV-1575 detector.

Plant Material The pericarps of I. fargesii were collected in Sichuan, China, in August 1998, and identified by Prof. Chun-Shu Yang. A voucher specimen has been deposited at Beijing University of Chinese Medicine.

Extraction and Isolation The dried pericarps of $I$. fargesii were extracted with $\mathrm{MeOH}$ to yield an $\mathrm{MeOH}$ extract $(600 \mathrm{~g})$. The extract $(240 \mathrm{~g})$ was chromatographed over a silica gel (Silica gel $60 \mathrm{~N})$, eluting with a step gradient of $\mathrm{CH}_{2} \mathrm{Cl}_{2}(100 \%), \mathrm{CH}_{2} \mathrm{Cl}_{2}$-EtOAc (9:1), $\mathrm{CH}_{2} \mathrm{Cl}_{2}$-EtOAc $(1: 1), \mathrm{CH}_{2} \mathrm{Cl}_{2}-\mathrm{EtOAc}(1: 9)$, EtOAc $(100 \%)$, EtOAc-MeOH $(9: 1)$ and EtOAc-MeOH $(1: 1)$ to yield 8 fractions $(1-8)$. Fraction $3(8.5 \mathrm{~g})$ was separated by column chromatography on silica gel (Wako-gel C-300), eluting with $n$-hexane-EtOAc $(4: 1)$ to yield 9 fractions. The eighth fraction $(850 \mathrm{mg})$ was separated by column chormatography on Sephadex LH-20 using $\mathrm{MeOH}$ and then purified by HPLC on a Cosmosil 5C18-AR-II column $(10 \times 250 \mathrm{~mm})$ with $\mathrm{MeOH}-\mathrm{H}_{2} \mathrm{O}\left(13: 7\right.$, at a flow rate of $\left.2.0 \mathrm{ml} \mathrm{min}^{-1}\right)$ to yield compounds $1(30 \mathrm{mg}), \mathbf{2}(3 \mathrm{mg})$ and $\mathbf{3}(40 \mathrm{mg})$. Fraction $1(4.4 \mathrm{~g})$ was first subjected to silica gel (Wako-gel C-300) column chromatography, eluting with $n$-hexane-EtOAc $(4: 1)$ to yield 8 fractions. The first fraction $(4.4 \mathrm{~g})$ was purified by column chromatography on a silica gel, eluting with $n$-hexane/EtOAc ( $4: 1)$ to yield $7(55 \mathrm{mg})$ and $\mathbf{8}(15 \mathrm{mg})$, which were identified by analysis of their NMR data as well as by comparison with previously reported NMR data. ${ }^{10,11)}$ The fourth fraction $(1.6 \mathrm{~g})$ was separated by column chromatography on a silica gel, eluting with $n$-hexane/EtOAc $(4: 1)$ to yield compound $5(26 \mathrm{mg})$. The fifth fraction $(750 \mathrm{mg})$ was purified by HPLC on a Cosmosil 5C18-AR-II column $(10 \times 250 \mathrm{~mm})$ with $\mathrm{MeOH}-\mathrm{H}_{2} \mathrm{O}(19: 1$, at a flow rate of $2.0 \mathrm{ml} \mathrm{min}^{-1}$ ) to yield compound $4(12 \mathrm{mg})$.

11-O-(E)-Cinnamoyl-2-oxo-6-deoxyneoanisatin (1): Amorphous powder, $[\alpha]_{\mathrm{D}}^{15}+71.3^{\circ}(c=1.74, \mathrm{MeOH})$. IR (film) $\mathrm{cm}^{-1}: 3854(\mathrm{OH}), 1823(\beta$-lactone), $1735(\mathrm{C}=\mathrm{O}), 1633$ (aroma.). UV $\lambda_{\max }(\mathrm{EtOH}) \mathrm{nm}: 284(\varepsilon 23500)$. EIMS $m / z$ (rel. int.): $440\left(\mathrm{M}^{+}, 11\right), 131$ (100). HR-EI-MS $m / z: 440.1468$ (Calcd for $\left.\mathrm{C}_{24} \mathrm{H}_{24} \mathrm{O}_{8}: 440.1471\right) .{ }^{1} \mathrm{H}$ - and ${ }^{13} \mathrm{C}-\mathrm{NMR}$ data, see Table 1.

11-O-(Z)-Cinnamoyl-2-oxo-6-deoxyneoanisatin (2): Amorphous powder, $[\alpha]_{\mathrm{D}}^{15}+69.9^{\circ}(c=0.51, \mathrm{MeOH})$. IR (film) cm $\mathrm{cm}^{-1}: 3475(\mathrm{OH}), 1821(\beta-\mathrm{lac}-$ tone), $1745(\mathrm{C}=\mathrm{O}), 1632$ (aroma.). UV $\lambda_{\max }(\mathrm{EtOH}) \mathrm{nm}: 282(\varepsilon 21500)$. EIMS $m / z$ (rel. int.): $440\left(\mathrm{M}^{+}, 33\right), 131$ (100). HR-EI-MS $m / z: 440.1466$ (Calcd for $\mathrm{C}_{24} \mathrm{H}_{24} \mathrm{O}_{8}: 440.1471$ ). ${ }^{1} \mathrm{H}$ - and ${ }^{13} \mathrm{C}-\mathrm{NMR}$ data, see Table 1.

4-Allyl-2-(3-methylbut-2-en-1-yl)phenol (4): A colorless oil. IR (film) $\mathrm{cm}^{-1}$ : $3385(\mathrm{OH}), 1639$ (aroma.). UV $\lambda_{\max }(\mathrm{EtOH}) \mathrm{nm}: 280$ ( $\varepsilon$ 1200). EIMS $m / z$ (rel. int.): $202\left(\mathrm{M}^{+}, 72\right), 185$ (5), 161 (15), 133 (13). HR-EI-MS $m / z: 202.1355$ (Calcd for $\left.\mathrm{C}_{14} \mathrm{H}_{18} \mathrm{O}: 202.1358\right) .{ }^{1} \mathrm{H}-\mathrm{NMR}\left(\mathrm{C}_{6} \mathrm{D}_{6}\right) \delta: 1.56(6 \mathrm{H}$, bs, $\left.\mathrm{H}_{3}-13,14\right), 3.20\left(2 \mathrm{H}\right.$, dd, $\left.J=6.6,1.8 \mathrm{~Hz}, \mathrm{H}_{2}-7\right), 3.32(2 \mathrm{H}, \mathrm{d}, J=7.3 \mathrm{~Hz}$, $\left.\mathrm{H}_{2}-10\right), 4.99(1 \mathrm{H}, \mathrm{dt}, J=10.2,1.8 \mathrm{~Hz}, \mathrm{H}-9), 5.02(1 \mathrm{H}, \mathrm{dt}, J=16.8,1.8 \mathrm{~Hz}, \mathrm{H}-$ 9), $5.34(1 \mathrm{H}, \mathrm{tq}, J=7.3,1.5 \mathrm{~Hz}, \mathrm{H}-11), 5.91(1 \mathrm{H}, \mathrm{ddt}, J=16.8,10.2,6.6 \mathrm{~Hz}$, $\mathrm{H}-8), 6.50(1 \mathrm{H}, \mathrm{d}, J=8.1 \mathrm{~Hz}, \mathrm{H}-6), 6.85(1 \mathrm{H}, \mathrm{dd}, J=8.1,2.2 \mathrm{~Hz}, \mathrm{H}-5), 6.96$ $(1 \mathrm{H}, \mathrm{d}, J=2.2 \mathrm{~Hz}, \mathrm{H}-3) .{ }^{13} \mathrm{C}-\mathrm{NMR}\left(\mathrm{C}_{6} \mathrm{D}_{6}\right) \delta: 17.9(\mathrm{C}-13), 25.9(\mathrm{C}-14), 30.0$ (C-10), 40.1 (C-7), 115.2 (C-9), 115.8 (C-6), 122.9 (C-11), 127.4 (C-2),
127.6 (C-5), 130.5 (C-3), 132.1 (C-4), 133.3 (C-12), 138.5 (C-8), 153.1 (C$1)$.

4-Allyl-2-(2-methylbut-3-en-2-yl)phenol (5): A colorless oil. IR (film) $\mathrm{cm}^{-1}$ : $3497(\mathrm{OH}), 1638$ (aroma.). UV $\lambda_{\max }(\mathrm{EtOH}) \mathrm{nm}: 280$ ( $\varepsilon$ 2100). EIMS $m / z$ (rel. int.): $202\left(\mathrm{M}^{+}, 96\right), 185$ (5), 161 (25), 133 (13). HR-EI-MS $m / z$ : 202.1354 (Calcd for $\left.\mathrm{C}_{14} \mathrm{H}_{18} \mathrm{O}: 202.1358\right) .{ }^{1} \mathrm{H}-\mathrm{NMR}\left(\mathrm{CDCl}_{3}\right) \delta: 1.40$ $\left(6 \mathrm{H}, \mathrm{s}, \mathrm{H}_{3}-13,14\right), 3.33\left(2 \mathrm{H}, \mathrm{d}, J=7.0 \mathrm{~Hz}, \mathrm{H}_{2}-7\right), 5.06(1 \mathrm{H}, \mathrm{dd}, J=16.8$ $1.3 \mathrm{~Hz}, \mathrm{H}-9), 5.08(1 \mathrm{H}, \mathrm{dd}, J=10.3,1.3 \mathrm{~Hz}, \mathrm{H}-9), 5.32(1 \mathrm{H}, \mathrm{dd}, J=17.6$, $0.7 \mathrm{~Hz}, \mathrm{H}-12), 5.32(1 \mathrm{H}, \mathrm{dd}, J=10.6,0.7 \mathrm{~Hz}, \mathrm{H}-12), 5.70(1 \mathrm{H}, \mathrm{s}, \mathrm{OH}), 5.97$ $(1 \mathrm{H}, \mathrm{ddt}, J=16.8,10.3,7.0 \mathrm{~Hz}, \mathrm{H}-8), 6.19(1 \mathrm{H}, \mathrm{dd}, J=17.6,10.6 \mathrm{~Hz}, \mathrm{H}-11)$, $6.77(1 \mathrm{H}, \mathrm{d}, J=8.4 \mathrm{~Hz}, \mathrm{H}-6), 6.99(1 \mathrm{H}, \mathrm{dd}, J=8.4,2.2 \mathrm{~Hz}, \mathrm{H}-5), 7.05(1 \mathrm{H}, \mathrm{d}$ $J=2.2 \mathrm{~Hz}, \mathrm{H}-3) .{ }^{13} \mathrm{C}-\mathrm{NMR}\left(\mathrm{CDCl}_{3}\right) \delta: 26.9(\mathrm{C}-13,14), 39.7(\mathrm{C}-7), 40.3(\mathrm{C}-$ 10), 113.4 (C-12), 115.4 (C-9), 117.7 (C-6), 126.4 (C-3), 128.1 (C-5), 131.9 (C-2), 132.0 (C-4), 138.0 (C-8), 147.9 (C-11), 153.0 (C-1).

Methylation of 7 with TMSCHN $_{2}$ To a $\mathrm{MeOH}(0.5 \mathrm{ml})$ solution of 7 $(6.0 \mathrm{mg})$ was added $75 \mu \mathrm{l}$ of $\mathrm{TMSCHN}_{2}(2.0 \mathrm{M}$ in ether), and the mixture was stood for $6 \mathrm{~h}$. The solvent was removed in vacuo to leave the residue, which was purified by prep. TLC with benzene/ $\mathrm{CH}_{2} \mathrm{Cl}_{2}(1: 1)$ to give $7 \mathbf{a}(0.67 \mathrm{mg})$, $7 \mathbf{b}(1.2 \mathrm{mg}), 7 \mathbf{c}(2.6 \mathrm{mg}), 7 \mathbf{d}(0.63 \mathrm{mg}), 7 \mathrm{e}(0.72 \mathrm{mg})$, and $7 \mathbf{f}(1.0 \mathrm{mg})$ as amorphous powders.

7a: ${ }^{1} \mathrm{H}-\mathrm{NMR}\left(\mathrm{CDCl}_{3}\right) \delta: 3.36(2 \mathrm{H}, \mathrm{ddd}, J=6.6,1.6,1.6 \mathrm{~Hz}), 3.37(2 \mathrm{H}, \mathrm{d}$, $J=6.6 \mathrm{~Hz}), 3.55(2 \mathrm{H}$, ddd, $J=6.3,1.6,1.6 \mathrm{~Hz}), 3.58(3 \mathrm{H}, \mathrm{s}), 5.05(\mathrm{ddd}$ $J=9.9,3.3,1.6 \mathrm{~Hz}$ ), 5.07 (ddd, $J=9.9,3.3,1.6 \mathrm{~Hz}$ ), 5.08 (ddd, $J=16.8,3.3$, $1.6 \mathrm{~Hz}$ ), 5.09 (ddd, $J=16.8,3.3,1.6 \mathrm{~Hz}$ ), 5.13 (ddd, $J=9.9,3.3,1.6 \mathrm{~Hz}$ ), 5.15 (ddd, $J=16.5,3.3,1.6 \mathrm{~Hz}$ ), $5.96(\mathrm{ddt}, J=16.8,9.9,6.6 \mathrm{~Hz}), 5.98$ (ddt $J=16.8,9.9,6.7 \mathrm{~Hz}), 6.03(\mathrm{ddt}, J=16.5,9.9,6.3 \mathrm{~Hz}), 6.92(\mathrm{~d}, J=8.2 \mathrm{~Hz})$, $7.02(\mathrm{~d}, J=8.2 \mathrm{~Hz}), 7.06(\mathrm{~d}, J=2.2 \mathrm{~Hz}), 7.09(\mathrm{dd}, J=8.2,2.2 \mathrm{~Hz}), 7.15(\mathrm{dd}$ $J=8.2,2.2 \mathrm{~Hz}$ ), 7.16 (d, $J=2.2 \mathrm{~Hz}), 7.34(2 \mathrm{H}, \mathrm{s})$. EI-MS $m / z$ (rel. int.): 412 $\left(\mathrm{M}^{+}, 88\right), 279$ (3), 133 (3). HR-EI-MS $m / z$ : 412.2035 (Calcd for $\mathrm{C}_{28} \mathrm{H}_{28} \mathrm{O}_{3}$ : 412.2038).

7b: ${ }^{1} \mathrm{H}-\mathrm{NMR}\left(\mathrm{CDCl}_{3}\right) \delta: 3.34(2 \mathrm{H}, \mathrm{ddd}, J=6.6,1.6,1.6 \mathrm{~Hz}), 3.37(2 \mathrm{H}$, ddd, $J=6.6,1.6,1.6 \mathrm{~Hz}), 3.41(3 \mathrm{H}, \mathrm{s}), 3.52(2 \mathrm{H}, \mathrm{ddd}, J=6.8,1.6,1.6 \mathrm{~Hz})$, $3.79(3 \mathrm{H}, \mathrm{s}), 5.05$ (ddd, $J=9.9,3.3,1.6 \mathrm{~Hz}), 5.06$ (ddd, $J=9.9,3.3,1.6 \mathrm{~Hz}$ ), 5.07 (ddd, $J=16.8,3.3,1.6 \mathrm{~Hz}$ ), 5.08 (ddd, $J=16.8,3.3,1.6 \mathrm{~Hz}$ ), 5.12 (ddd, $J=10.2,3.6,1.6 \mathrm{~Hz}$ ), 5.15 (ddd, $J=16.8,3.6,1.6 \mathrm{~Hz}$ ), 5.96 (ddt, $J=16.8$, $9.9,6.6 \mathrm{~Hz}$ ), 5.97 (ddt, $J=16.8,9.9,6.6 \mathrm{~Hz}$ ), 6.04 (ddt, $J=16.8,10.2$, $6.8 \mathrm{~Hz}), 6.91(\mathrm{~d}, J=8.2 \mathrm{~Hz}), 6.93(\mathrm{~d}, J=8.2 \mathrm{~Hz}), 7.05(\mathrm{dd}, J=8.2,2.2 \mathrm{~Hz})$, 7.08 (d, $J=2.2 \mathrm{~Hz}$ ), 7.16 (dd, $J=8.2,2.2 \mathrm{~Hz}), 7.26(2 \mathrm{H}, \mathrm{d}, J=2.2 \mathrm{~Hz})$. EI-MS $m / z$ (rel. int.): $426\left(\mathrm{M}^{+}, 100\right), 385$ (2), 344 (7). HR-EI-MS $m / z: 426.2192$ (Calcd for $\mathrm{C}_{29} \mathrm{H}_{30} \mathrm{O}_{3}: 426.2195$ ).

7c: ${ }^{1} \mathrm{H}-\mathrm{NMR}\left(\mathrm{CDCl}_{3}\right) \delta: 3.35(2 \mathrm{H}, \mathrm{ddd}, J=6.6,1.6,1.6 \mathrm{~Hz}), 3.37(2 \mathrm{H}, \mathrm{d}$, $J=6.6 \mathrm{~Hz}), 3.54(2 \mathrm{H}$, ddd, $J=6.7,1.6,1.6 \mathrm{~Hz}), 3.92(3 \mathrm{H}, \mathrm{s}), 5.04$ (ddd, $J=9.9,3.3,1.6 \mathrm{~Hz}$ ), 5.06 (ddd, $J=10.2,3.3,1.6 \mathrm{~Hz}), 5.08(2 \mathrm{H}, \mathrm{ddd}, J=16.8$, $3.3,1.6 \mathrm{~Hz}$ ), 5.10 (ddd, $J=9.9,3.6,1.6 \mathrm{~Hz}$ ), 5.15 (ddd, $J=16.8,3.6,1.6 \mathrm{~Hz}$ ), 5.25 (s), 5.95 (ddt, $J=16.8,9.9,6.6 \mathrm{~Hz}), 5.97$ (ddt, $J=16.8,10.2,6.7 \mathrm{~Hz}$ ), 6.08 (ddt, $J=16.8,9.9,6.7 \mathrm{~Hz}), 6.41(\mathrm{~s}), 6.92(\mathrm{~d}, J=8.0 \mathrm{~Hz}), 7.00(\mathrm{~d}$, $J=8.4 \mathrm{~Hz}), 7.06(\mathrm{dd}, J=8.0,2.2 \mathrm{~Hz}), 7.07 \quad(\mathrm{dd}, J=2.2 \mathrm{~Hz}), 7.16(\mathrm{~d}$, $J=2.2 \mathrm{~Hz}), 7.22(\mathrm{dd}, J=8.4,2.2 \mathrm{~Hz}), 7.23(\mathrm{~d}, J=2.2 \mathrm{~Hz}), 7.26(\mathrm{~d}, J=2.2 \mathrm{~Hz})$. EI-MS $m / z$ (rel. int.): $412\left(\mathrm{M}^{+}, 100\right), 371$ (4), 330 (25), 265 (2), 133 (2). HR-EI-MS $m / z: 412.2037$ (Calcd for $\mathrm{C}_{28} \mathrm{H}_{28} \mathrm{O}_{3}: 412.2038$ ).

7d: ${ }^{1} \mathrm{H}-\mathrm{NMR}\left(\mathrm{CDCl}_{3}\right) \delta: 3.37(4 \mathrm{H}$, ddd, $J=6.61 .8,1.8 \mathrm{~Hz}), 3.54(2 \mathrm{H}$, ddd, $J=6.6,1.8,1.8 \mathrm{~Hz}), 3.56(3 \mathrm{H}, \mathrm{s}), 3.81(3 \mathrm{H}, \mathrm{s}), 5.05$ (dd, $J=10.2$, $1.8 \mathrm{~Hz}), 5.07(\mathrm{dd}, J=10.2,1.8 \mathrm{~Hz}), 5.08(\mathrm{dd}, J=16.8,1.8 \mathrm{~Hz}), 5.09$ (dd, $J=16.8,1.8 \mathrm{~Hz}), 5.12(\mathrm{dd}, J=10.2,1.8 \mathrm{~Hz}), 5.15(\mathrm{dd}, J=16.8,1.8 \mathrm{~Hz}), 5.96$ (ddt, $J=16.8,10.2,6.6 \mathrm{~Hz}$ ), 5.97 (ddt, $J=16.8,10.2,1.8 \mathrm{~Hz}$ ), 6.05 (ddt, $J=16.8,10.2,6.6 \mathrm{~Hz}), 6.92(\mathrm{~d}, J=9.1 \mathrm{~Hz}), 7.01(\mathrm{~d}, J=8.2 \mathrm{~Hz}), 7.13(\mathrm{dd}$ $J=9.1,2.2 \mathrm{~Hz}), 7.14(\mathrm{~d}, J=2.2 \mathrm{~Hz}), 7.18(\mathrm{dd}, J=8.2,2.2 \mathrm{~Hz}), 7.20(\mathrm{~d}$, $J=2.2 \mathrm{~Hz}$ ), 7.39 (d, $J=2.2 \mathrm{~Hz}), 7.40$ (d, $J=2.2 \mathrm{~Hz}$ ). EI-MS $\mathrm{m} / \mathrm{z}$ (rel. int.): $426\left(\mathrm{M}^{+}, 100\right), 385$ (2), 344 (3), 279 (4). HR-EI-MS m/z: 426.2204 (Calcd for $\left.\mathrm{C}_{29} \mathrm{H}_{30} \mathrm{O}_{3}: 426.2195\right)$.

7e: ${ }^{1} \mathrm{H}-\mathrm{NMR}\left(\mathrm{CDCl}_{3}\right) \delta: 3.35(2 \mathrm{H}, \mathrm{ddd}, J=6.6,1.8,1.8 \mathrm{~Hz}), 3.36(2 \mathrm{H}$, ddd, $J=6.6,1.8,1.8 \mathrm{~Hz}), 3.40(3 \mathrm{H}, \mathrm{s}), 3.49(2 \mathrm{H}, \mathrm{ddd}, J=6.6,1.8,1.8 \mathrm{~Hz})$, $3.78(3 \mathrm{H}, \mathrm{s}), 3.79(3 \mathrm{H}, \mathrm{s}), 5.05(2 \mathrm{H}, \mathrm{dd}, J=10.2,1.8 \mathrm{~Hz}), 5.07(2 \mathrm{H}, \mathrm{dd}$, $J=16.8,1.8 \mathrm{~Hz}$ ), 5.09 (dd, $J=10.2,1.8 \mathrm{~Hz}), 5.15(\mathrm{dd}, J=16.8,1.8 \mathrm{~Hz}), 5.97$ $(2 \mathrm{H}, \mathrm{ddt}, J=16.8,10.2,6.6 \mathrm{~Hz}), 6.06(\mathrm{ddt}, J=16.8,10.2,6.6 \mathrm{~Hz}), 6.89(\mathrm{~d}$ $J=8.2 \mathrm{~Hz}), 6.91(\mathrm{~d}, J=8.5 \mathrm{~Hz}), 7.09(\mathrm{dd}, J=8.2,2.2 \mathrm{~Hz}), 7.15(\mathrm{dd}, J=8.5$, $2.2 \mathrm{~Hz}), 7.16(2 \mathrm{H}, \mathrm{d}, J=2.2 \mathrm{~Hz}), 7.31(\mathrm{~d}, J=2.3 \mathrm{~Hz}), 7.36(\mathrm{~d}, J=2.3 \mathrm{~Hz})$. EIMS $m / z$ (rel. int.): $440\left(\mathrm{M}^{+}, 55\right)$. HR-EI-MS $m / z$ : 440.2356 (Calcd for $\left.\mathrm{C}_{30} \mathrm{H}_{32} \mathrm{O}_{3}: 440.2352\right)$

7f: ${ }^{1} \mathrm{H}-\mathrm{NMR}\left(\mathrm{CDCl}_{3}\right) \delta: 3.36(2 \mathrm{H}, \mathrm{ddd}, J=6.9,1.6,1.6 \mathrm{~Hz}), 3.37(2 \mathrm{H}$, ddd, $J=6.6,1.6,1.6 \mathrm{~Hz}), 3.54(2 \mathrm{H}$, ddd, $J=6.6,1.6,1.6 \mathrm{~Hz}), 3.79(3 \mathrm{H}, \mathrm{s})$, $3.91(3 \mathrm{H}, \mathrm{s}), 5.04$ (ddd, $J=10.2,3.31 .6 \mathrm{~Hz}), 5.06$ (ddd, $J=9.9,3.3,1.6 \mathrm{~Hz}$ ), 5.09 (ddd, $J=9.9,3.6,1.6 \mathrm{~Hz}), 5.09(2 \mathrm{H}, \mathrm{dd}, J=16.9,3.3,1.6 \mathrm{~Hz}), 5.15$ (dd, $J=16.8,1.6 \mathrm{~Hz}$ ), 5.95 (ddt, $J=16.9,10.2,6.9 \mathrm{~Hz}), 5.97$ (ddt, $J=16.9,9.9$, 
$6.9 \mathrm{~Hz}$ ), 6.10 (ddt, $J=16.8,9.9,6.6 \mathrm{~Hz}), 6.43$ (s), 6.90 (d, $J=8.5 \mathrm{~Hz}), 6.99$ (d, $J=8.5 \mathrm{~Hz}), 7.10$ (dd, $J=8.5,2.2 \mathrm{~Hz}), 7.16(\mathrm{~d}, J=2.2 \mathrm{~Hz}), 7.20$ (dd, $J=8.5$, $2.2 \mathrm{~Hz}), 7.21(\mathrm{~d}, J=2.2 \mathrm{~Hz}), 7.31(\mathrm{~d}, J=2.1 \mathrm{~Hz}), 7.35$ (d, $J=2.1 \mathrm{~Hz})$. EI-MS $m / z$ (rel. int.): $426\left(\mathrm{M}^{+}, 100\right), 344$ (4), 147 (2), 132 (2). HR-EI-MS $m / z$ : 426.2201 (Calcd for $\mathrm{C}_{29} \mathrm{H}_{30} \mathrm{O}_{3}: 426.2195$ ).

Neuroprotective Assay Neuronal viability was determined in the MTT reduction assay as previously described. ${ }^{16)}$ Briefly, cortical neurons from fetuses of E18 rats were cultured in poly-L-lysine-coated 96-well plates in DMEM $/ 10 \%$ FBS at a density of $2 \times 10^{5}$ cells $/ \mathrm{cm}^{2}$ for $24 \mathrm{~h}$, and then the medium was changed to DMEM/1\% $\mathrm{N}_{2}$ supplement containing test samples. After a further $48 \mathrm{~h}$ culture, neuronal viability was determined by the MTT assay.

Acknowledgements We thank Dr. M. Tanaka and Ms. Y. Okamoto for measurements of NMR and MS spectra. This work was supported in part by a Grant-in-Aid for Scientific Research from the Ministry of Education, Culture, Sports, Science, and Technology of Japan (Priority Area, 18032085; 19790027) and the Open Research Fund from the Promotion and Mutual Aid Corporation for Private Schools of Japan.

\section{References and Notes}

1) Huang J., Liu H., Yang C., Ye J., Xue Y., Chin. Trad. Herb. Drugs, 31, 54-58 (2000).

2) Fukuyama Y., Huang J.-M., "Studies in Natural Products Chemistry," Vol. 32, ed. by Atta-ur-Rahman, Elsevier, Amasterdam, 2005, pp. 395-429.

3) Yamada K., Takada S., Nakamura S., Hirata Y., Tetrahedron, 24, 199-229 (1968).
4) Kouno I., Hashimoto M., Enjoji S., Takahashi M., Kaneto H., Yang C.S., Chem. Pharm. Bull., 39, 1773-1778 (1991).

5) Sy L.-K., Saunders R. M. K., Brown G. D., Phytochemistry, 44, 1099-1108 (1997).

6) Vahirua-Lechat I., Menut C., Roig B., Bessiere J. M., Lamaty G., Phytochemistry, 43, 1277-1279 (1996).

7) Shibuya M., Abe K., Nakahashi Y., Chem. Pharm. Bull., 26, 26712673 (1978).

8) Jakupovic J., Pathak V. P., Bohlmann F., King R. M., Robinson H., Phytochemistry, 26, 803-807 (1987).

9) Fujita M., Itokawa H., Sashida Y., Chem. Pharm. Bull., 20, 212-213 (1972).

10) Kouno I., Iwamoto C., Kameda Y., Tanaka T., Yang Y.-S., Chem. Pharm. Bull., 42, 112-114 (1994).

11) Kouno I., Morisaki T., Hara Y., Yang C.-S., Chem. Pharm. Bull., 39, 2606-2608 (1991).

12) Kouno I., Hashimoto A., Kawano N., Yang C.-S., Chem. Pharm. Bull., 37, 1291-1292 (1991)

13) Chen J.-J., Wang T.-Y., Hwang T.-L., J. Nat. Prod., 71, 212-217 (2008).

14) Fukuyama Y., Nakade K., Minoshima Y., Yokoyama R., Zhai H., Mitsumoto Y., Bioorg. Med. Chem. Lett., 12, 1163-1166 (2002).

15) Moriyama M., Huang J.-M., Yang C.-S., Hioki H., Kubo M., Harada K., Fukuyama Y., Tetrahedron, 63, 4243-4249 (2007).

16) Zhai H., Inoue T., Moriyama M., Esumi T., Mitsumoto Y., Fukuyama Y., Biol. Pharm. Bull., 28, 289-293 (2005).

17) The methylated positions of $7 \mathbf{a}-\mathbf{f}$ were elucidated by their NOESY spectra and comparison of their NMR data with those of 7. 